\title{
Germination of dormant seeds of Stylosanthes humilis as promoted by ethylene accumulation in closed environments
}

\author{
Dimas Mendes Ribeiro and Raimundo Santos Barros*
}

Departamento de Biologia Vegetal, Universidade Federal de Viçosa, CEP 36571-000, Viçosa, MG, Brasil; *Corresponding author: rsbarros@ufv.br

Received: 02/02/2004, Accepted: 02/07/2004

Germination of scarified dormant seeds of Townsville stylo (Stylosanthes humilis) is very low in Petri dishes, but may be appreciable in sealed Erlenmeyer flasks if ethylene accumulates in their atmospheres. When ethylene in the flask atmosphere was fixed by a mercuric perchlorate solution, emanation of the gaseous regulator and germination of dormant seeds were drastically decreased. On the other hand, ethylene produced by dormant seeds and accumulated in the flask atmosphere led to a further enhancement of ethylene accumulation and a corresponding increased seed germination. Germination of both dormant and non-dormant seeds did not occur when ethylene biosynthesis was completely blocked.

Key words: Townsville stylo, closed environments, dormancy, ethylene, germination, seeds.

Germinação de sementes dormentes de Stylosanthes humilis promovida por acúmulo de etileno em ambientes fechados: A germinação de sementes dormentes escarificadas de estilosante (Stylosanthes humilis) é muito baixa em placas de Petri, mas pode ser considerável em frascos de Erlenmeyer selados devido a um acúmulo de etileno em sua atmosfera. Quando esse etileno foi adsorvido por solução de perclorato de mercúrio, a emanação do regulador gasoso das sementes dormentes e sua germinação foram drasticamente diminuídas. O etileno produzido pelas sementes dormentes, ao difundir-se na atmosfera dos frascos, promoveu maior acúmulo do próprio gás e um correspondente aumento da germinação. Sementes dormentes e nãodormentes não germinaram quando a biossíntese do regulador foi completamente bloqueada.

Palavras-chave: estilosante, ambientes fechados, dormência, etileno, germinação, sementes.

\section{INTRODUCTION}

Seeds of Townsville stylo (Stylosanthes humilis H.B.K.) exhibit a relatively hard cover and when freshly harvested also show a physiological dormancy which is gradually overcome during post-harvest ageing. Such dormancy is broken by several stress contidions, for example, low $\mathrm{pH}$ solutions (Pelacani, 2004), heavy metals (Delatorre and Barros, 1996), thiourea (Delatorre et al., 1997), selenium compounds (Barros and Freitas 2000, 2001), high temperatures (Argel and Humphreys, 1983) and compounds such as 2-chloroethylphosphonic acid (CEPA) and 1-aminocyclopropane-1-carboxylic acid (ACC) (Burin et al., 1987; Vieira and Barros, 1994). All these conditions seem associated with ethylene production. In fact, inhibitors of ethylene biosynthesis and action greatly reduce germination of non-dormant Townsville stylo seeds (Burin et al., 1987; Vieira and Barros, 1994). Recently Pelacani et al. (2004a) demonstrated that imbibed nondormant seeds produced 10- to 12 fold more ethylene than dormant ones. Ethylene is thus thought to be the natural dormancy-breaking agent in these seeds.

A differential behavior of Townsville seeds has been observed when they are imbibed in open (Petri-dishes) or closed containers (sealed Erlenmeyer flask). In the open, germination of dormant seeds is very low or null, but when enclosed in flasks, germination may sometimes attain up to $30 \%$. Moreover, when treated with inhibitors of ethylene biosynthesis, germination of non-dormant seeds is very low in Petri-dishes and relatively high in sealed flasks. This situation is identical to the one displayed by lettuce (Lactuca sativa) (Saini et al., 1989) and common lambsquarters 
(Chenopodium album) seeds (Machabée and Saini, 1991). These authors suggested that seeds under closed conditions may exhibit a change in metabolism that could bring about modifications in their atmosphere and thus explain the observed results. It seems probable that ethylene emanated from a few dormant seeds and accumulated in the closed environment in such a way as to induce their own germination and that of neighbouring seeds. This hypothesis was examined in the present work.

\section{MATERIALS AND METHODS}

Plant material and germination conditions: Plants of Townsville stylo (Stylosanthes humilis H.B.K.) were grown in $3.0 \mathrm{~L}$ plastic pots in a green-house in Viçosa $\left(20^{\circ} 45^{\prime} \mathrm{S}\right.$, $42^{\circ} 15^{\prime} \mathrm{W}$ ), Minas Gerais State, Brazil. Mature pods were periodically harvested and kept under laboratory conditions $\left(21-28^{\circ} \mathrm{C}\right)$. In this way, seeds of several post-harvest ages and with corresponding different dormancy stages were available for the assays.

The seeds were freed from the husks, scarified with fine sandpaper, sterilized with $\mathrm{NaOCl} 0.5 \%$ for $10 \mathrm{~min}$, and thoroughly washed with distilled water. They were then transferred to glass Petri dishes of $9.5 \mathrm{~cm}$ diameter or to Erlenmeyer flasks of 25 or $50 \mathrm{~mL}$ (depending on the assays), each containing two layers of Whatman $\mathrm{n}^{\circ} 1$ filter paper lining the bottom. These assemblies were sterilized at $105^{\circ} \mathrm{C}$ for 4h. Petri dishes were provided with $10 \mathrm{~mL}$ and the 25 or 50 $\mathrm{mL}$ Erlenmeyer flasks with 2.0 and $3.0 \mathrm{~mL}$, respectively (sufficient to completely wet the paper layers) of the control germination medium, $\mathrm{pH} 7.0$, containing $0.05 \%$ Tween 80 , or with a mixture $0.1 \mathrm{mmol} . \mathrm{L}^{-1} 2$-aminoethoxyvinylglycine (AVG) and $1.0 \mathrm{mmol} \cdot \mathrm{L}^{-1} \mathrm{Co}\left(\mathrm{NO}_{3}\right)_{2}$.

Flasks sealed with rubber serum caps and containing from 10 to 100 seeds (usually 25 or 50 ) seeds and Petri dishes with 50 seeds were kept in a growth chamber (Forma Scientific Inc., Ohio, USA) at $30^{\circ} \mathrm{C}$ in the dark for the germination tests. Seeds with a protruded radicle of about $3.0 \mathrm{~mm}$ long was considered germinated. Daily germination counts were carried out for a period of four or five days (Burin et al., 1987).

Assays with and quantitation of ethylene: Ethylene employed as a dormancy-breaking agent was produced from CEPA as described in Abeles et al. (1992). Known amounts of ethylene (as measured by gas chromatography, see below) were injected into the flasks through the rubber caps with a syringe.

To create an ethylene-free atmosphere inside the Erlenmeyer flasks, a polypropylene cup $(26.0 \mathrm{~mm}$ diameter,
$6.0 \mathrm{~mm}$ high) was placed on the paper layers lining the bottom of the flasks; cups were also lined with three layers of filter paper and received a 0.25 mol. $\mathrm{L}^{-1}$ mercuric perchlorate solution $(0.75$ or $1.0 \mathrm{~mL})$. Under such conditions no trace of ethylene could be detected in the flask. Ethylene was released from the perchlorate solution by adding an equal volume of 4.0 mol. $\mathrm{L}^{-1} \mathrm{NaCl}$ solution (see Abeles 1973). In this experimental system the seeds were placed around the cup. An identical assembly was also employed to investigate the influence of germinating non-dormant seeds upon the dormant ones. Dormant seeds were distributed within the cup whereas the non-dormant ones were placed around it.

Ethylene was quantitated as described by Saltveit and Yang (1987). A $1.0 \mathrm{~mL}$ air sample was taken from the Erlenmeyer flasks and injected in a gas chromatograph (Hewlett-Packard 5890, series II), equipped with a flameionization detector and a stainless steel column $(1.0 \mathrm{~m}$ x 6.0 $\mathrm{mm}$ ) of Porapak-N, 80-100 mesh. Nitrogen carrier gas and hydrogen flow rates were $30 \mathrm{~mL} \cdot \mathrm{min}^{-1}$ and air $320 \mathrm{~mL} \cdot \mathrm{min}^{-1}$. Column, injector and detector temperatures were 60,100 and $150^{\circ} \mathrm{C}$, respectively. Ethylene peaks were registered on an HP 3395 A integrator coupled to the chromatograph and quantified by comparison with authentic ethylene standard.

Statistical design: The statistical design of the assays was based on a completely randomized distribution with five replicates (flasks or Petri dishes) of a variable number of seeds (depending on the experiment, see Results and Discussion). Germination percentage was transformed into $\arcsin (\% \mathrm{G} /$ $100)^{1 / 2}$ for statistical analysis. Differences between means of both germination and ethylene content were tested for significance according to Scott and Knott (1974). Means followed by different letters were significantly different at the $5 \%$ level.

\section{RESULTS AND DISCUSSION}

The atmosphere of enclosed environments may be deeply modified as a result of gaseous exchanges with imbibed seeds contained therein. Changes in $\mathrm{CO}_{2}$ and $\mathrm{O}_{2}$ concentrations can affect the dormancy state and germination of seeds. Several preliminary attempts were made to examine a possible effect of $\mathrm{CO}_{2}$ accumulation on the internal atmosphere of sealed flasks with both dormant and non-dormant seeds. Strips of filter paper imbibed with either $10 \% \mathrm{KOH}$ solution (to fix $\mathrm{CO}_{2}$ ) or water were placed against the internal flask walls. Germination and dormancy breakage were nevertheless always identical under both conditions. As for $\mathrm{O}_{2}$ variations, 
germination of non-dormant seeds was also identical whether it occurred in Petri dishes and in open or closed Erlenmeyer flasks. As shown throughout this work, especially in fig 1 and table 1, the effect of an enclosed atmosphere on germination of dormant seeds can be ascribed to ethylene accumulation rather than to a decrease in $\mathrm{O}_{2}$ concentration. The fresh matter of an imbibed Townsville stylo seed is about $5.15 \mathrm{mg} ; 25$ or 50 seeds were enclosed in 25 or $50 \mathrm{~mL}$ Erlenmeyer flasks, respectively, i.e., in a volume about 195 fold larger. Thus variations in $\mathrm{CO}_{2}$ and $\mathrm{O}_{2}$ concentration in closed flasks would have been too small to cause any appreciable alteration in the state of dormancy or seed germination. In order to verify seed viability, at the end of the experiments seeds were routinely treated with $10^{-3}$ mol.L $\mathrm{L}^{-1}$ thiourea solution (Delatorre et al. 1997), a treatment which produced a final germination rate (summing up germination before and after thiourea treatment) usually greater than $90 \%$.

Response of dormant seeds to ethylene produced by themselves and accumulated in closed containers is shown in table 1 . That ethylene was associated with dormancy breakage in seeds of Townsville stylo is shown in figure 1. Such behaviour is similar to seeds of several other species described

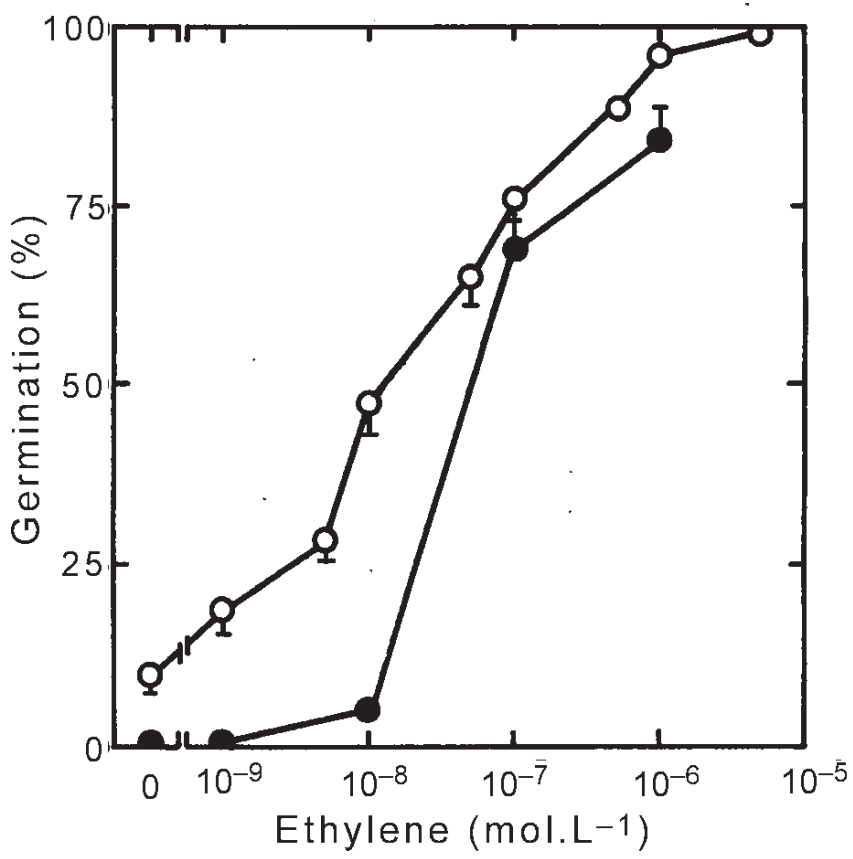

Figure 1. Response of dormant seeds (post-harvest age $7 \mathrm{~d}$ ) to ethylene. Each replication consisted of 25 seeds in a 25 $\mathrm{mL}$ sealed Erlenmeyer flask with $2.0 \mathrm{~mL}$ germination medium (O) or AVG plus $\mathrm{Co}^{2+}(\bullet)$ Germination was registered on the $5^{\text {th }}$ day. Bars represent standard errors and are not shown if smaller than symbols. by Kepazyńsky and Kepazyńsky (1997). It may also be seen in figure 1 that when ethylene biosynthesis was inhibited by AVG plus $\mathrm{Co}^{2+}$, the response to the regulator was diminished, especially at lower concentrations. When no ethylene was injected in the flasks, germination of non-inhibited seeds was about $10 \%$; under the same conditions no germination occurred in inhibited seeds. These results show that the gaseous regulator constitutes a real requirement for dormancy breakage and that some ethylene might have been synthesized by non-inhibited seeds. This was confirmed by the fact that no ethylene was found in flasks with inhibited seeds at the end of the experiment; on the order hand, ethylene $\left(10^{-8} \mathrm{~mol} . \mathrm{L}^{-1}\right)$ was found in flasks with non-inhibited seeds. At this concentration inhibited seeds began to display a measurable response, suggesting constitute a threshold concentration to trigger seed dormancy breakage.

Seed response to increasing time periods of enclosure is shown in table 1. No germination occurred in Petri-dishes and open flasks, both increasing germination and the observed ethylene accumulation would appear to be a consequence of seed enclosure. It is known that metabolic activities of dormant seed tissues in closed environments can lead to changes in ethylene concentrations (Saini et al., 1989; Machabée and Saini, 1991). However, to date, the consequences of this phenomenon have not been examined in detail.

Table 1. Effects of flask sealing duration on germination of dormant seeds (post-harvest age $42 \mathrm{~d}$ ) and on ethylene accumulation. Erlenmeyer flasks $(25 \mathrm{~mL})$ containing 25 seeds and $2.0 \mathrm{~mL}$ germination medium were sealed with rubber serum caps for the times shown, at the end of which ethylene was measured and the flasks opened and air exhausted in a fume cupboard. Germination was registered on the $5^{\text {th }}$ day.

\begin{tabular}{ccc}
\hline $\begin{array}{c}\text { Sealing period } \\
(\mathrm{h})\end{array}$ & $\begin{array}{c}\text { Germination } \\
(\%)\end{array}$ & $\begin{array}{c}\text { Ethylene } \\
\left(\text { nmol.flask }^{-1}\right)\end{array}$ \\
\hline Petri dish & $0.0-$ & $*$ \\
0 (open flask) & $0.0 \mathrm{~d}$ & $0.0 \mathrm{c}$ \\
12 & $0.0 \mathrm{~d}$ & $0.0 \mathrm{c}$ \\
24 & $4.0 \pm 1.7 \mathrm{c}$ & $0.09 \pm 0.02 \mathrm{~b}$ \\
48 & $10.4 \pm 1.6 \mathrm{~b}$ & $0.49 \pm 0.14 \mathrm{~b}$ \\
72 & $19.2 \pm 2.3 \mathrm{a}$ & $1.21 \pm 0.20 \mathrm{a}$ \\
96 & $20.0 \pm 2.1 \mathrm{a}$ & $1.24 \pm 0,13 \mathrm{a}$ \\
120 & $21.6 \pm 2.0 \mathrm{a}$ & $1.27 \pm 0,15 \mathrm{a}$ \\
\hline
\end{tabular}

* Not determined 


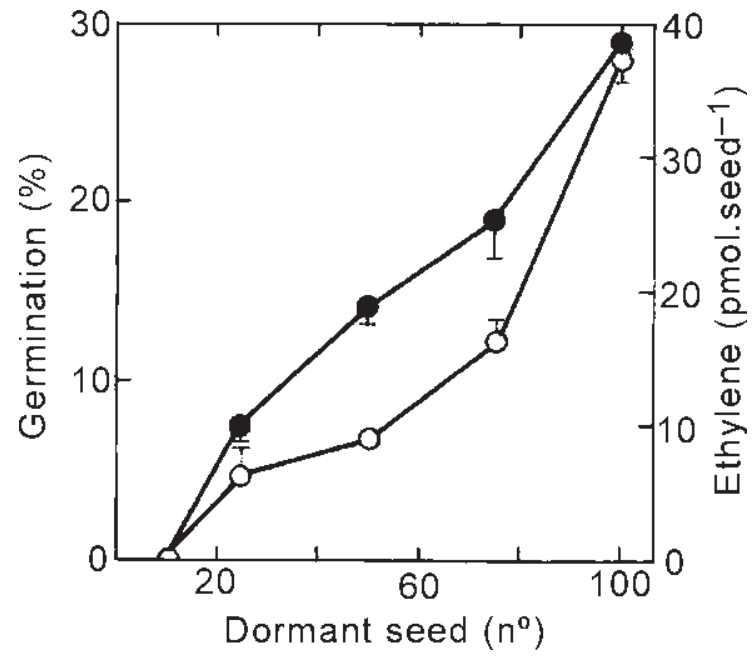

Figure 2. Effects of the number of dormant seeds (postharvest age $12 \mathrm{~d}$ ) contained in $50 \mathrm{~mL}$ sealed Erlenmeyer flasks (3.0 $\mathrm{mL}$ germination medium) upon their own germination and ethylene production. Germination (O) counts and ethylene ( $\bullet$ ) measurement were carried out on the $4^{\text {th }}$ day. To calculate the amount of ethylene accumulated in nmol per flask, multiply by the corresponding number of seeds. Bars represent standard errors and are not shown if smaller than symbols.

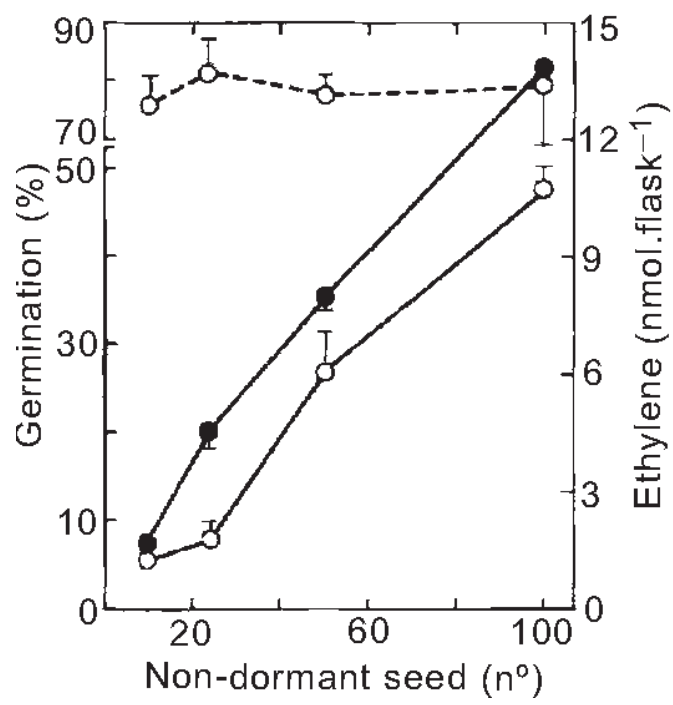

Figure 3. Effects of number of non-dormant seeds (postharvest age $287 \mathrm{~d}$ ) on the germination of 25 dormant ones (7 d), both contained in a $50 \mathrm{~mL}$ flask with $3.0 \mathrm{~mL}$ germination medium. Dormant seeds were placed in the polypropylene cup and non-dormant placed around it. Germination (dormant - o-) counts and measurement of ethylene (- - - ) produced by both dormant and nondormant seeds were carried out on the $4^{\text {th }}$ day. Germination of non-dormant seeds (- - - -) is also shown. Bars represent standard errors and are not shown if smaller than symbols.
Germination and ethylene production by dormant seeds in closed environments, though expressive, exhibited a relatively low upper limit, which was attained on the 3rd day levelling off thereafter (table 1). This relatively weak response was also seen when a higher ethylene concentration was achieved by increasing the number of dormant seeds in flasks of identical volume (maximum germination about $30 \%$, figure 2). Probably, this was a result of the low amount of ethylene accumulated in the flasks. In fact ethylene biosynthesis capacity of dormant Townsville seeds is very low (Barros and Delatorre, 1998) due to their extremely low amounts of free ACC (Pinheiro, 2004). Since germinating nondormant seeds synthesize relatively large amounts of ethylene (Pelacani et al., 2004) their effects upon germination of dormant seeds were investigated by germinating the two kinds of seeds in the same flask. As the number of non-dormant seeds increased, germination of dormant seeds (constant number of 25 seeds) increased in parallel due to the increasing amounts of ethylene in the flasks (figure 3). It remains to be determined whether under natural conditions the ethylene produced by germinating seeds in the soil could trigger dormancy breakage of neighbouring seeds. Figure 3 also illustrates that, irrespective of their number in the flasks, germination of non-dormant seeds was about $80 \%$, which is a much higher figure than the germination percentage of dormant seeds. As both kind of seeds were under exactly the same ethylene concentration in the flask it is concluded that non-dormant seeds are much more sensitive to the gaseous regulator. In fact laboratory tests have shown non-dormant seeds to be up to 50 -fold more sensitive to ethylene than dormant seeds (Barros, unpublished).

Figure 2 shows that the larger the number of dormant seeds in a flask, the larger the amount of ethylene produced per seed, suggesting that the ethylene accumulated in the flask atmosphere may enhance its own biosynthesis. This could also be deduced from figure 1; the response to added ethylene was much greater in non-inhibited seeds than in inhibited ones, especially under the lower ethylene concentrations employed. The phenomenon was further investigated with an ethylenefree atmosphere by absorbing the gas produced in a mercuric perchlorate solution. Germination was halved in dormant seeds and decreased about $25 \%$ in non-dormant ones as compared to their respective controls (table 2). Ethylene fixed by perchlorate as measured at the end of the assay following its release from perchlorate, proved to be at a lower concentration than in flasks without perchlorate. Hence, when 
Table 2. Effects of ethylene removal from and its ensuing release into the $50 \mathrm{~mL}$ flask atmospheres upon germination ( 50 seeds, $3.0 \mathrm{~mL}$ germination medium) and upon ethylene production by dormant (post-harvest $14 \mathrm{~d}$ ) and nondormant ( $303 \mathrm{~d}$ ) seeds. Cups inside the flasks received 0.75 $\mathrm{mL}$ control or mercuric perchlorate solution (2 sets). On the $3^{\text {rd }}$ day $0.75 \mathrm{~mL}$ germination medium (control), perchlorate or $\mathrm{NaCl}$ were added to the cups through the rubber seals with a syringe. Germination counts and ethylene measurement were carried out on the $5^{\text {th }}$ day.

\begin{tabular}{lcc}
\hline Treatment & $\begin{array}{c}\text { Germination } \\
(\%)\end{array}$ & $\begin{array}{c}\text { Ethylene } \\
\left(\text { nmol.flask }^{-1}\right)\end{array}$ \\
\hline Dormant & & \\
Control & $6.0 \pm 1.3 \mathrm{a}$ & $1.02 \pm 0.12 \mathrm{a}$ \\
Perchlorate $\rightarrow$ Perchlorate & $3.2 \pm 0.8 \mathrm{~b}$ & $0.39 \pm 0.04 \mathrm{~b}$ \\
Perchlorate $\rightarrow \mathrm{NaCl}$ & $6.4 \pm 0.7 \mathrm{a}$ & $1.13 \pm 0.14 \mathrm{a}$ \\
& & \\
Non-dormant & & \\
Control & $66.4 \pm 3.2 \mathrm{a}$ & $5.10 \pm 0.27 \mathrm{a}$ \\
Perchlorate $\rightarrow$ Perchlorate & $48.8 \pm 3.7 \mathrm{~b}$ & $2.21 \pm 0.19 \mathrm{~b}$ \\
Perchlorate $\rightarrow \mathrm{NaCl}$ & $63.2 \pm 3.1 \mathrm{a}$ & $5.85 \pm 0.18 \mathrm{a}$ \\
& & \\
\hline
\end{tabular}

ethylene was produced but not captured, this led to further production and accumulation with a corresponding increase in seed germination. If ethylene were released to the flask atmosphere in the middle of the experiment an increase in ethylene concentration well above the one fixed by perchlorate was observed attaining values identical to those of flasks with an undisturbed atmosphere (control - no perchlorate). Likewise germination of non-dormant seeds increased and that of dormant seeds doubled (table 2). Thus, despite the low ethylene biosynthetic capacity of dormant seeds, a contribution of accumulated ethylene in triggering its own synthesis and stimulating further germination was observed.

Although it appears that ethylene emanating from a few germinating dormant seeds led to an accumulation of the gaseous regulator within the closed container, inducing thus dormancy breakage, the possibility remains that dormant seeds were able to escape from the ethylene requirement, germinating as a result of other causes. Ethylene requirement was demonstrated with dormant seeds by inhibiting ethylene biosynthesis (figure 1). However, non-dormant Townsville stylo seeds treated with $\mathrm{AVG}$ and $\mathrm{Co}^{2+}$ exhibited a high germination and produced trace amounts of ethylene (Pelacani et al., 2004b), a phenomenon also shown by thermoinhibited seeds of lettuce (Saini et al., 1989). In order to completely inhibit ethylene production seeds were treated with AVG plus
Table 3. Effects of inhibitors of ethylene biosynthesis under an ethylene-free atmosphere on germination and ethylene production by dormant (post-harvest age $18 \mathrm{~d}$ ) and nondormant ( $303 \mathrm{~d}$ ) seeds (50 seeds) In each treatment, the cups contained $1.0 \mathrm{~mL}$ mercuric perchlorate solution. Seeds were placed around the cups in the medium containing 3.0 $\mathrm{mL}$ control germination medium or AVG $\left(0.1 \mathrm{mmol} . \mathrm{mL}^{-1}\right)$ plus $\mathrm{Co}^{2+}\left(1.0 \mathrm{mmol} . \mathrm{mL}^{-1}\right)$ over one day period. Thereafter the cups received $1.0 \mathrm{~mL}$ perchlorate solution and flasks were sealed. Germination counts and ethylene measurement were carried out on the $5^{\text {th }}$ day.

\begin{tabular}{lcc} 
Treatment & $\begin{array}{c}\text { Germination } \\
(\%)\end{array}$ & $\begin{array}{c}\text { Ethylene } \\
\left(\text { nmol.flask }^{-1}\right)\end{array}$ \\
\hline Dormant & & \\
Perchlorate, control & $6.4 \pm 1.4 \mathrm{a}$ & $0.91 \pm 0.13 \mathrm{a}$ \\
Perchlorate, $\mathrm{AVG}+\mathrm{Co}^{2+}$ & $0.0 \mathrm{~b}$ & $0.0 \mathrm{~b}$ \\
Non-dormant & & \\
Perchlorate, control & $54.4 \pm 1.7 \mathrm{a}$ & $3.74 \pm 0.11 \mathrm{a}$ \\
Perchlorate, $\mathrm{AVG}+\mathrm{Co}^{2+}$ & $0.0 \mathrm{~b}$ & $0.0 \mathrm{~b}$
\end{tabular}

$\mathrm{Co}^{2+}$ for $24 \mathrm{~h}$ and afterwards the mercuric perchlorate solution $(1.0 \mathrm{~mL})$ was added into the cups and the Erlenmeyer flasks sealed (Ribeiro and Barros, 2004). With this system, no ethylene was synthesized either by dormant or non-dormant seed. Germination, accordingly, was null in both kinds of seeds (table 3). As no ethylene was found in the flask atmospheres any enhanced production of the gas became meaningless. The feeble germination shown by dormant seeds in the treatment under an ethylene-free atmosphere and submitted to germination control medium could be ascribed to the ethylene synthesized being momentarily retained in the atmosphere before its capture by the perchlorate solution as also shown in table 2. Despite of the rapid capture of ethylene by the perchlorate solution (Ribeiro and Barros, 2004), injection of $5.10^{-5} \mathrm{~mol} . \mathrm{L}^{-1}$ of the gas into the system described sufficed to stimulate $65 \%$ and $25 \%$ germination in non-dormant and dormant seeds, respectively. Furthermore, release of ethylene from the perchlorate solution in the middle of the experiment led to results similar to those reported in table 2 .

In conclusion, containerized dormant seeds of Townsville stylo were shown to germinate as a result of ethylene accumulation in the closed environment. This phenomenon was limited, however, probably due to the low biosynthetic capacity for ethylene biosynthesis of dormant seeds. Despite that biosynthesis, enhanced ethylene action within the limit of response appears to occur, leading to an increase in germination of dormant seeds. 
Acknowledgments: D.M.R. and R.S.B. were recipients of scholarships from Board for Post-Graduate Scientific Training (CAPES) and the Brazilian Council for Advancement of Science and Technology (CNPq). Thanks are also due to the State of Minas Gerais Research Foundation (FAPEMIG) for the financial support granted on several occasions.

\section{REFERENCES}

Abeles FB (1973) Ethylene in Plant Biology. Academic Press, New York.

Abeles FB, Morgan PW, Saltveit Jr ME (1992) Ethylene in Plant Biology. $2^{\text {nd }}$ edn. Academic Press, New York.

Argel RJ, Humphreys LR (1983) Environment effects on seed development and hardseededness in Stylosanthes hamata cv. Verano I. Temperature. Aust. J. Agr. Res. 34:261-270.

Barros RS, Delatorre CA (1998) 1-Aminocyclopropane-1carboxylic acid-stimulated germination of Stylosanthes humilis seed is inhibited by abscisic acid. Seed Sci. Technol. 26:319-24

Barros RS, Freitas AWP (2000) Stimulation of germination of dormant seeds of Townsville stylo by selenomethionine. Seed Sci. Technol. 28:241-247.

Barros RS, Freitas AWP (2001) Selenomethionone as a dormancy-breaking agent in seeds of Stylosanthes humilis. Acta Physiol. Plant. 23:279-284.

Burin ME, Barros RS, Rena AB (1987) Chemical regulation of endogenous dormancy in seeds of Stylosanthes humilis HBK. Turrialba 37:281-285.

Delatorre CA, Barros RS (1996) Germination of dormant seeds of Stylosanthes humilis as related to heavy metal ions. Biol. Plant. 38: 269-274.

Delatorre CA, Barros RS, Vieira HD (1997) Germinação de sementes de Stylosanthes humilis em resposta à tiouréia. Rev. Bras. Fisiol. Veget. 9:43-53.
Kepazyńsky J, Kepazyńsky E (1997) Ethylene in seed dormancy and germination. Physiol. Plant. 101:720-726.

Machabée S, Saini HS (1991) Differences in the requirement for endogenous ethylene during germination of dormant and non-dormant seeds of Chenopodium album L. J. Plant. Physiol. 138:97-101.

Pelacani CR, Barros RS, Ribeiro DM, Frigeri RBC (2004a) Breaking dormancy of Stylosanthes humilis seeds with low $\mathrm{pH}$ solutions. Acta Physiol. Plant. (in press)

Pelacani CR, Ribeiro DM, Barros RS, Frigeri RBC (2004b) Germination of dormant seeds of Stylosanthes humilis as affected by organic acids. Seed Sci. Technol. 33 (in press)

Pinheiro FJA (2004) Quebra do dormência de sementes de Stylosanthes humilis HBK por compostos selênicos. Viçosa, Universidade Federal de Viçosa. Doctorate thesis.

Ribeiro DM, Barros RS (2004) A technique devised for detecting the ethylene requirement for germination as illustrated with Stylosanthes humilis seeds. Seed Sci. Technol. 32 (in press)

Saini HS, Consolación ED, Bassi PK, Spencer MS (1989) Control processes in the induction and relief of thermoinhibition of lettuce seed germination. Actions of phytochrome and endogenous ethylene. Plant Physiol. 90:311-315

Saltveit-Jr ME, Yang SF (1987) Ehtylene. In: Rivier L, Crozier A (eds), Principles and Practice of Plant Hormone Analysis, Vol. 2, pp.367-396. Academic Press, London.

Scott AJ, Knott M (1974) A cluster analysis method for grouping means in the analysis of variance. Biometrics 30:507-519.

Vieira HD, Barros RS (1994) Responses of seed of Stylosanthes humilis to germination regulators. Physiol. Plant. 92:17-20. 